\title{
A STUDY ON MAIZE CULTIVATION UNDER DRIP AND CONVENTIONAL
}

\section{FERTIGATION METHODS}

\author{
B. GOWTHAM SINGH ${ }^{1} \&$ G. RAKESH ${ }^{2}$ \\ ${ }^{I}$ Teaching Associate, Dr. Y. S. R Horticultural University, Parvathipuram, India \\ ${ }^{2}$ Research Associate, Dr. Y. S. R Horticultural University, Venkataramannagudem, India
}

\begin{abstract}
Study has been made, to compare the economics of cost of production in maize, for drip fertigation and conventional fertigation was carried out at field irrigation laboratory, of department of Soil and Water Engineering, College of Agricultural Engineering, Bapatla during rabi 2015-16. Though, the initial capital investment was high in drip irrigation system, the cumulative benefit would be greater and considering the longer life of the system. The benefit cost ratio of maize was analyzed, by calculating the annual cost, cost of cultivation, seasonal total cost, yield produced, selling price, income from produce. Highest income from produce was recorded, for the treatment T1 (Rs.109800.00), followed by the treatment T2 (Rs.100440.00), whereas T3 recorded (Rs.85320.00). The lowest net seasonal income was recorded, for the treatment T4 (Rs.57960.00) was estimated by multiplying the total production of maize value, with prevailing market rate.

KEYWORDS: Conventional Fertigation, Highest Income \& Prevailing Market Rate.
\end{abstract}

Received: Sep 20, 2017; Accepted: Oct 11, 2017; Published: Nov 22, 2017; Paper Id.: IJASRDEC201744

\section{INTRODUCTION}

Maize or Indian corn (Zea mays L.) is one of the most important cereal crops, in the global agricultural economy both as a food for man and feed for animal. According to 2012/13 FAO estimates, worldwide production of maize is $872 \mathrm{Mt}$, from $177 \mathrm{Mha}$. India stands at 6th position, with 2.5 Mt from 8.67 Mha. By 2020 AD, the requirement of maize for various sectors will be around $100 \mathrm{Mt}$, of which, the poultry sector demand alone will be around $31 \mathrm{Mt}$ in India (Directorate of Economics and Statistics. 2015). With intention of achieving evergreen revolution, intensive research in maize, such as fertigation and variety development etc. has been started anticipating its importance, for food and feed. It has been noticed that, during the year 2012-13, in combined Andhra Pradesh, the production of maize is 48.55 lakh tonnes from 972 thousand hectares, where as in truncated Andhra Pradesh the production of maize is 19.10 lakh tones, from 308 thousand hectares (Spices Board India, 2015).

\section{MATERIALS AND METHODS}

The experiment was designed for the RBD, with four main treatments with five replications. The four main treatments T1, T2, T3 and T4 were fertigated, with fertilizer injection pump, venturi injector, fertilizer tank and control respectively. The treatments are named as follows for convenience: 


\begin{tabular}{|c|c|}
\hline T1 - & Drip + Fertilizer injectionpump \\
\hline T2 - & Drip + Venturi injector \\
\hline T3 - & Drip + Fertilizer tank \\
\hline T4 - & Control \\
\hline
\end{tabular}

Economic analysis explains how prices are determined under conditions of competition or monopoly, why business fluctuations occur, and what force promotes or retard economic growth. The question whether, business was run profitably or not determined, by an analysis called economic analysis. The objective of economic analysis is to verify the use of various inputs of production and income incurred. The cost economics of drip system, with different fertigation equipment were analyzed from the data collected which includes the initial cost of the system components and costs of accessories. The expenditure incurred from field preparation, to harvest was worked out and expressed as Rs ha ${ }^{-1}$. The green chilli yield was computed per hectare and, the total income was worked out, based on the prevailed minimum market rate of Rs.18.00 per kg. Net returns were obtained by subtracting the cost of cultivation, from gross return. The cost of drip system for one hectare was worked out based on, current market rates. The life of the drip system was assumed to be 6 years. Prevailing market price of drip components, from a standard firm was used. Interest on capital investment was taken as $8.0 \%$ per annum. The benefit cost ratio (BCR) was worked out, by using the formula suggested by Palaniappan (1985).

$$
\mathrm{BCR}=\frac{\text { Gross return }\left(\mathrm{Rs} \mathrm{ha}^{-1}\right)}{\text { Total cost of cultivation }\left(\mathrm{Rs} \mathrm{ha}^{-1}\right)}
$$

\section{RESULTS AND DISCUSSIONS}

The life span of drip system varies from 6 to 10 years depending, upon quality and maintenance of drip system. Hence, a normal life span of 6 years was considered for computation. Though, the initial capital investment was high in drip irrigation system, the cumulative benefit would be greater and considering the longer life of the system.

The benefit cost ratio of maize crop were analyzed and shown in Table 1, by calculating the annual cost, cost of cultivation, seasonal total cost, yield produced, selling price, income from produce. From the Table 1, highest income from produce was recorded for the treatment T1 (Rs.109800.00), followed by the treatment T2 (Rs.100440.00) whereas T3 recorded (Rs.85320.00). The lowest net seasonal income was recorded for the treatment T4 (Rs.57960.00) was estimated, by multiplying the total production of maize value with prevailing market rate.

Benefit cost ratio (BCR) for maize crop and depicts that, the different costs of production and economic returns of producing one hectare of maize, under conventional as well as drip fertigation system, using fertilizer equipments. Total cost of production under fertilizer injection pump was high, i.e. Rs.109800. This is because of installation cost of fertilizer injection pump. The results also revealed that, BCR was again high for fertilizer injection pump treatment. BCR was calculated from incremental benefits and costs of fertilizer injection pump, over conventional irrigation method of experimental site. It is evident from the table that, BCR was the highest for the T1 of 1.48 and the lowest, for the T4 of 1.15. Venturi injector occupied the second position for BCR of 1.41, whereas T3 recorded BCR as 1.20. Table 1, clearly indicates that, at different methods of fertilizer application results had significant difference. 
Table 1: Cost Economics of Maize Crop in all Four Treatments

\begin{tabular}{|c|c|c|c|c|c|}
\hline $\begin{array}{l}\text { S. } \\
\text { No }\end{array}$ & Particulars & T1 & $\mathbf{T 2}$ & $\mathbf{T 3}$ & T4 \\
\hline 1 & $\begin{array}{l}\text { Annual Cost }\left(\mathrm{Rs} \mathrm{ha}^{-1}\right) \text { of drip } \\
\text { system } \\
\text { (Depreciation, Interest, } \\
\text { Repair \& Maintenance) }\end{array}$ & 19577 & 16862 & 16294 & 0 \\
\hline 2 & $\begin{array}{l}\text { Cost of Cultivation }\left(\mathrm{Rs} \mathrm{ha}^{-1}\right) \\
\text { (FYM, Seed, Fertilizers \& } \\
\text { Pesticides, including labour } \\
\text { charges) }\end{array}$ & 54351 & 54351 & 54351 & 50351 \\
\hline 3 & Seasonal total cost $(1+2) \mathrm{Rs} \mathrm{ha}^{-1}$ & 73928 & 71213 & 70645 & 50351 \\
\hline 4 & Yield produced $\left(\mathrm{t} \mathrm{ha}^{-1}\right)$ & 6.10 & 5.58 & 4.74 & 3.22 \\
\hline 5 & $\begin{array}{l}\text { Selling price }\left(\text { Rs t }^{-1}\right) @ \text { Rs } 18 \\
\mathrm{~kg}^{-1}\end{array}$ & 18000 & 18000 & 18000 & 18000 \\
\hline 6 & Income from produce $(\mathrm{Rs})(4 \times 5)$ & 109800 & 100440 & 85320 & 57960 \\
\hline 7 & Benefit cost ratio (6/3) & 1.48 & 1.41 & 1.20 & 1.15 \\
\hline
\end{tabular}

After estimation of benefit cost ratio, it was finally concluded that, drip fertigation experiments was more profitable rather than traditional hand broadcasting method. From findings of the study, it was found that, fertilizer applied with fertilizer injection pump had absolute advantages over traditional, as well as venturi and fertilizer tank method of fertilizer application. Moreover, the analysis showed that fertilizer injection pump got priority, due to higher BCR, over traditional irrigation system rather than venturi injector system. The results are in line, with results of Thiyagarajan et al. (2011).

\section{CONCLUSIONS}

The present study concluded that, for maize crop cultivation the total annual cost, for the drip fertigation system was Rs. 54351. The benefit cost ratio of 1.48 was recorded, for T1 followed by T2 (1.41) and for T3 (1.20). The least value of benefit cost ratio was recorded, in $\mathrm{T} 4$ as 1.15 . On the basis of benefit cost ratio treatment $\mathrm{T} 1$ is recommended.

\section{REFERENCES}

1. Amos R. N, Jens B. A, Symon M. 2012. On-farm evaluation of yield and economic benefit of short term maize legume intercropping systems under conservation agriculture in Malawi. Elsevier field crops research. 132: (149-157).

2. Iken J. E. and Amusa N. A, 2004. Maize research and production in Nigeria. African Journal of Biotechnology 3(6): (302307).

3. Muhammad T, Asif T, Asghar A, Muhammad A and Allah W. 2008. Comparative Yield Performance of Different Maize (Zea mays L.) Hybrids under Local Conditions of Faisalabad-Pakistan. Pakistan Journal of Life and Social Sciences. 6(2): (118120).

4. MujtabaM, ImranH. S, Nazim H andWazid A. S.2003. Performance of maize varieties as affected by different NP levels, Asian Journal of plant Sciences, 2(7): (535-538).

5. Ramkrishaniah D, 1992. Economics of maize production in two district of western UP. Indian farmers Digest 15 (4): 9-10. 
